\title{
HUBUNGAN ANTARA PENGETAHUAN CARA MEMELIHARA KEBERSIHAN GIGI DAN MULUT DENGAN OHI-S PADA IBU HAMIL DI PUSKESMAS RANOMUUT KOTA MANADO
}

\author{
Novarita Mariana Koch \\ Jurusan Keperawatan Gigi Poltekkes Kemenkes Manado Jl. R.W. Mongisidi Malalayang Manado \\ e-mail : kochnovarita@gmail.com
}

\begin{abstract}
ABSTRAK
Latar Belakang : Implementasi batasan sehat itu bagi orang Indonesia itu, yakni bila fisik sehat, rohani sehat, hubungan diantara masyarakat juga sehat. Masyarakat termasuk ibu hamil sangat menginginkan keadaan yang sehat pula yang juga akan ditunjukkan dari keadaan perilaku berupa perilaku pengetahuan yang terjadi melalui panca indera manusia. Ibu hamil mengalami banyak perubahan hormonal sehingga kesehatannya permasuk kesehatan gigi dan mulut sering terabaikan. Kehamilan adalah suatu proses fisiologi yang dapat menimbulkan perubahan-perubahan pada tubuh wanita, baik fisik maupun psikis karena pengaruh natural hormon. Tujuan: Tujuan penelitian ini adalah untuk mengetahui "Hubungan Pengetahuan Cara Memelihara Kebersihan Gigi dan Mulut dengan OHI-S pada Ibu Hamil di Puskesmas Ranomuut Kota Manado". Metode : Jenis penelitian bersifat analitik dengan pendekatan cross sectional study, sampel 72 orang dan penelitian dilakukan selama dua minggu yaitu minggu pertama dan keempat Juni 2018. Metode yang digunakan accidental sampling dengan kriteria inklusi. Pengetahuan diukur menggunakan kuesioner dan kebersihan gigi dan mulut diukur dengan kriteria OHI-S. Hasil: Hasil analisis menggunakan uji chi-square, tidak memenuhi syarat karena terdapat nilai ekspetasi kurang dari 5 sebanyak 2 sel $(33,3 \%)$, maka digunakan uji kolmogorov-smirnov diperoleh $p=000<0,05$ maka H0 di tolak dan H1 diterima, Kesimpulan: hasil ini memberi arti bahwa terdapat hubungan pengetahuan cara memelihara kebersihan gigi dan mulut dengan OHI-S pada ibu hamil di Puskesmas Ranomuut Kota Manado.
\end{abstract}

Keywords: Pengetahuan, OHI-S, Ibu Hamil.

\begin{abstract}
Background: Implementation of the healthy boundaries for the Indonesian people, namely if healthy physically, spiritually healthy, the relationship between the community is also healthy. Communities, including pregnant women, really want a healthy state which will also be shown from behavioral conditions in the form of knowledge behavior that occurs through the five human senses. Pregnant women experience many hormonal changes so that their health including oral and dental health is often overlooked. Pregnancy is a physiological process that can cause changes in a woman's body, both physically and psychologically because of the natural influence of hormones. Objective: The purpose of this study was to determine "Relationship of Knowledge on How to Maintain Oral and Dental Hygiene with OHI-S in Pregnant Women at Ranomuut Manado City Health Center". Method: This type of research is analytical with a cross sectional study approach, a sample of 72 people and the study was conducted for two weeks, namely the first and fourth weeks of June 2018. The method used was accidental sampling with inclusion criteria.
\end{abstract}


Knowledge was measured using a questionnaire and oral and dental hygiene was measured by the OHI-S criteria. Results: The results of the analysis used the chi-square test, did not fulfill the requirements because there were expectations of less than 5 as many as 2 cells $(33.3 \%)$, then the kolmogorov-smirnov test was obtained $\mathrm{p}=000<0.05$, H0 was rejected and $\mathrm{H} 1$ accepted, Conclusion: this result means that there is a relationship of knowledge about how to maintain dental and oral hygiene with OHI-S in pregnant women at the Ranomuut Health Center in Manado City.

\section{Keywords: Knowledge, OHI-S, Pregnant Women.}

\section{PENDAHULUAN}

Tatanan yang menghimpun berbagai upaya perorangan, kelompok dan masyarakat umum dibidang kesehatan secara terpadu dan saling mendukung guna tercapainya derajat kesehatan masyarakat yang setinggitingginya dalam Sistem Kesehatan Nasional tahun 2004 Masyarakat termasuk ibu hamil memerlukan keadaan sehat secara umum maupun lingkup sehat dalam bidang kesehatan gigi. ${ }^{1}$

Kesehatan gigi dan mulut merupakan bagian dari kesehatan secara menyeluruh, karenanya pemeliharaan kesehatan gigi dan mulut yang baik dan benar sangat mendukung terwujudnya kesehatan gigi dan mulut termasuk kesehatan ibu hamil pada umumnya ${ }^{2}$.

Hasil Riset Kesehatan Dasar untuk di Sulawesi Utara tahun 2007 adalah 29,8\% dan mengalami peningkatan menjadi $31,6 \%$ pada tahun 2013, tingginya masalah kesehatan gigi dan mulut disebabkan karena terabainya kebersihan gigi dan mulut ${ }^{3}$ Adanya pengetahuan yang baik tentang pemeliharaan kesehatan gigi dan mulut pada ibu hamil dapat menciptakan keadaan yang sehat secara utuh bagi ibu hamil. Kehamilan adalah suatu proses fisiologi yang dapat menimbulkan perubahan-perubahan pada tubuh wanita, baik fisik maupun psikis karena pengaruh natural hormon. ${ }^{1}$

Penelitian ini bertujuan untuk mengetahui Hubungan Pengetahuan Cara
Memelihara Kebersihan Gigi dan Mulut dengan OHI-S pada Ibu Hamil di Puskesmas Ranomuut Kota Manado.

\section{METODOLOGI}

Jenis penelitian analitik dengan pendekatan cross sectional study. Metode yang digunakan accidental sampling dengan kriteria inklusi Sampel diambil menggunakan metode accidental sampling dengan menggunakan kriteria inklusi yaitu bersedia untuk dijadikan sampel, hadir ditempat pada saat penelitian, sedang tidak sakit, sebanyak 72 responden. Pengetahuan diukur menggunakan kuesioner dan kebersihan gigi dan mulut diukur dengan kriteria OHI-S. Populasi penelitian yaitu semua ibu hamil yang datang di Puskesmas Ranomuut selama dua minggu yaitu minggu pertama dan keempat bulan Juni 2018. Instrumen penelitian yaitu kuesioner yang telah di uji validasi, formulir pemeriksaan OHI-S, alat dan bahan berupa diagnosa set (kaca mulut, sonde, pinset, excavator), nier beken, disclosing solution, kapas alkohol, masker dan handscoen.

\section{HASIL}

Hubungan pengetahuan dengan kriteria OHI$\mathrm{S}$ sebagian besar terdapat pada kriteria 
pengetahuan kurang baik dengan OHI-S buruk 25 orang $(34,7 \%)$, pengetahuan kurang baik dengan OHI-S sedang 14 orang $(19,4 \%)$, pengetahuan kurang baik dengan OHI-S baik 0 orang (0\%), sedangkan pengetahuan baik dengan OHI-S sedang yaitu 22 orang $(30,6 \%)$, pengetahuan baik dengan OHI-S baik 9 (12,5\%), pengetahuan baik dengan OHI-S buruk 2 orang $(2,8 \%)$. Hasil uji statistik chi-square antara hubungan pengetahuan cara memelihara kebersihan gigi dan mulut dengan OHI-S dengan taraf signifikansi 0,05 terdapat nilai expected kurang dari 5 yaitu sebanyak 2 sel $(33,3 \%)$ tidak boleh melebihi dari $20 \%$, maka analisis yang digunakan yaitu uji kolmogorovsmirnov dengan tingkat kemaknaan 95\% $(\alpha=0,05)$ diperoleh nilai $p=000<$ dari nilai $\alpha=0,05$, artinya terdapat hubungan yang bermakna antara kedua variabel yaitu pengetahuan cara memelihara kebersihan gigi dan mulut dengan OHI-S pada ibu hamil di Puskesmas Ranomuut Kota Manado.

\section{PEMBAHASAN}

Pengetahuan merupakan salah satu domain perilaku kesehatan yang sangat mempengaruhi kualitas hidup manusia termasuk ibu hamil. Pengetahuan yang merupakan hasil tahu dan terjadi setelah seseorang melakukan penginderaan terhadap suatu objek $^{1}$ Sebagian besar pengetahuan diperoleh melalui mata dan telinga. Pengetahuan atau kognitif merupakan domain yang sangat penting dalam membentuk tindakan seseorang (over behavior) ${ }^{4} \mathrm{Hal}$ ini menunjukkan bahwa adanya pengetahuan yang baik dan benar ibu hamil terhadap kesehatan gigi dan mulut maka dapat menunjang kebersihan gigi dan mulut ibu hamil. Menurut Hearther Jaher, dari University of North Carolina di Chapel Hill, Amerika Serikat dalam presentasinya di Asosiasi Internasional untuk penelitian gigi, menyatakan bahwa ibu hamil yang mengalami sakit gigi kronis atau berat dan menderita infeksi Periodontal, beresiko untuk melahirkan Bayi Berat Lahir Rendah (BBLR) karena pertumbuhannya terganggu ${ }^{5}$

Penelitian pada ibu hamil di Puskesmas Ranomuut didapatkan hasil bahwa hubungan pengetahuan dengan kriteria OHI-S sebagian besar terdapat pada kriteria pengetahuan kurang baik dengan OHI-S buruk. Hasil penelitian ini sejalan dengan penelitian Taha (2013) yang menyatakan bahwa terdapat hubungan pengetahuan tentang kebersihan gigi dan mulut dengan OHI-S. Hal ini menunjukkan bahwa semakin tinggi pengetahuan seseorang mengenai kesehatan gigi dan mulut maka semakin baik pula nilai OHI-S orang tersebut. ${ }^{6}$ Hasil penelitian Nurul (2016), juga menyatakan bahwa hampir sebagian besar ibu hamil memiliki tingkat pengetahuan yang cukup tentang kesehatan gigi dan mulut selama kehamilan ${ }^{7}$. Ibu hamil hanya tahu dan memahami tetapi perlu diikuti dengan rasa peduli dan tindakan untuk menjaga kebersihan gigi dan mulut. Artinya bahwa tahu saja tidak cukup dan perlu diikuti dengan rasa peduli dan tindakan $^{8}$.

\section{Notoatmodjo (2010), juga} menyatakan bahwa perilaku kesehatan dibagi menjadi 3 domain, yaitu pengetahuan, sikap, praktek atau tindakan. Merujuk bahwa perilaku seseorang tidak hanya terbentuk dari satu domain saja tetapi saling melengkapi satu dengan yang lain? Pengetahuan ibu hamil tentang kesehatan khususnya kesehatan gigi dan mulut akan sangat menentukan status kebersihan gigi dan mulut, sehingga semakin baik tingkat pengetahuan maka akan semakin baik juga tindakan seseorang dalam menjaga kebersihan gigi dan mulut. Menjaga kebersihan gigi dan mulut harus rutin dilakukan untuk mendapatkan gigi dan mulut yang sehat, diantaranya menyikat gigi, flossing dengan benang gigi, pola makan, dan kunjungan ke dokter gigi ${ }^{10}$. 
Menyikat gigi merupakan cara paling mudah dan murah untuk memelihara kesehatan gigi terutama pada ibu hamil yang biasanya malas melakukan aktifitas. Menyikat gigi adalah cara yang umum dianjurkan untuk membersihkan deposit lunak pada permukaan gigi dan gusi dan merupakan tindakan preventif. Frekuensi penyikatan gigi sebaiknya 3 kali dalam sehari, setiap kali sesudah makan dan sebelum tidur. Lamanya menyikat gigi yang dianjurkan adalah 5 menit, tetapi sesungguhnya itu terlalu lama umumnya orang melakukan penyikatan gigi maksimum 2 menit $^{11}$ Dental flossing atau benang gigi merupakan alat bantu untuk membersihkan sela gigi dan gusi. Daerah sela gigi memang daerah agak sulit dijangkau oleh sikat gigi ${ }^{10}$

Mengatur pola makan dengan membatasi komsumsi makanan atau ngemil di antara waktu makan berupa snack makanan bergula, roti dan coklat $^{12}$ Selain membatasi komsumsi makanan dengan pemanis, buah-buahan sangat baik bagi tubuh maupun bagi kesehatan gigi dan mulut. Apabila kita mengkomsumsi buah-buahan seperti, apel, jeruk, maka secara tidak langsung akan membantu membersihkan gigi secara alami ${ }^{13}$. Tindakan pencegahan terhadap kesehatan gigi dan mulut merupakan suatu keharusan supaya bisa mengetahui masalahmasalah di dalam rongga mulut yang tidak terlihat $^{10}$

\section{KESIMPULAN DAN SARAN}

\section{Kesimpulan}

Kesimpulan dari penelitian ini bahwa terdapat hubungan pengetahuan cara memelihara kebersihan gigi dan mulut dengan OHI-S pada ibu hamil di Puskesmas Ranomuut Kota Manado.

\section{Saran}

Saran yang dapat diberikan yaitu :

\section{Bagi ibu Hamil}

Meningkatkan dan memahami tentang cara menjaga kebersihan gigi dan mulut khususnya pada tindakan dan perilaku sehari-hari.

\section{Bagi peneliti selanjutnya}

Mengkaji mengenai tingkat pengetahuan tentang kesehatan gigi dan mulut dan manfaat menjaga kebersihan gigi dan mulut selama kehamilan dari tenaga kesehatan maupun kader posyandu

\section{DAFTAR PUSTAKA}

1. Triwibowo, C dan Pusphandani, M. E. 2015. Pengantar Dasar Ilmu Kesehatan Masyarakat. Nuha Medika

2. Kemenkes, RI. (2012). Pedoman Pemeliharaan Kesehatan Gigi dan Mulut Ibu Hamil dan Anak Usia Balita Bagi Tenaga Kesehatan Difasilitas Pelayanan Kesehatan

3. Kemenkes RI, (2013). Riset Kesehatan Dasar. Badan Penelitian dan Pengembangan Tenaga Kesehatan Departemen Kesehatan RI. Jakarta.

4. Notoatmodjo, S. 2007. Kesehatan Masyarakat Ilmu Dan Seni. PT Rineka Cipta. Jakarta.

5. Hermawan, R. (2010). Menyehatkan Daerah Mulut. Buku Biru, Jogjakarta

6. Taha, N.A.W. (2013). Hubungan Pengetahuan Cara Memelihara Kebersihan Gigi dan Mulut Dengan OHI-S Pada Ibu Hamil di Puskesmas Tikala Baru. Politeknik Kesehatan Manado.

7. Nurul, M. (2016). Hubungan Tingkat Pengetahuan Ibu Hamil Terhadap Kesehatan Gigi dan Mulut Selama Kehamilan di Puskesmas Ciputat Tangerang Selatan. Program Studi Ilmu Keperawatan FKIK UIN Syarif Hidayatullah, Jakarta.

8. Herijulianti, E., Indriani, T. S., Artini, S. (2002). Pendidikan Kesehatan Gigi. EGC, Jakarta. 
9. Notoatmodjo, S. 2007. Kesehatan Masyarakat Ilmu Dan Seni. PT Rineka Cipta. Jakarta.

10. Rahmadhan, A.G. (2010). Serba Serbi Kesehatan Gigi dan Mulut. Jakarta.

11. Putri, M.H., Herijulianti, E., \& Nurjannah, N. (2010). Ilmu Pencegahan Penyakit Jaringan Keras dan Jaringan Pendukung Gigi. EGC, Jakarta

12. Sriyono, N.W. (2005). Pengantar Ilmu Kedokteran Gigi Pencegahan. Medika Fakultas Kedokteran UGM, Yogyakarta.

13. Kusumawardani, E. (2011). Buruknya Kesehatan Gigi dan Mulut. Penerbit Siklus, Yogyakarta. 